\title{
Menguak Nilai Pendidikan Karakter Buku Bacaan Gerakan Literasi Nasional Kementerian Pendidikan dan Kebudayaan Kelas Rendah Sekolah Dasar
}

\author{
Winda Dwi Lestari ${ }^{1}$, Atiqa Sabardila ${ }^{2}$ \\ ${ }^{1}$ Universitas Muhammadiyah Surakarta, Surakarta, Jawa Tengah \\ ${ }^{2}$ Universitas Muhammadiyah Surakarta, Surakarta, Jawa Tengah \\ 1a310190209@student.ums.ac.id, 2as193@ums.ac.id
}

\begin{abstract}
The Ministry of Education and Culture launched a digital non-text reading book for children of low-grade Elementary School on the official website of gln.kemdikbud.go.id. The book contains character values that reflect the objective of the nation, which is developing students' characters. The purpose of this study was to describe the character values incorporated in the reading book by the Ministry of Education and Culture created for the low-grade and describe the suitability of its implementation according to Regulation No. 20 of 2018 of Ministry of Education and Culture. This research method was descriptive qualitative. The character value in the book was shown through the character's conversation, actions, or way of thinking. Furthermore, these values are marked and noted. Character values according to Permendikbud No. 20 Year 2018 and Pusat Kurikulum dan Perbukuan was used as a foundation. After the data was collected, the next step was data analysis. The data collection techniques used were reading, taking notes, and writing. The results of this study showed that 9 character education values were including 23 social care values, 10 hard work values, 9 religious values, 2 tolerance values, 1 environmental care value, 1 selfreliance value, 1 patriotism, 1 responsibility value, and 1 fondness to read value. Those values developed from the 5 main character values of the nation's character proclaimed in the regulation of the Minister of Education and Culture No. 20 of 2018 such as spirituality, nationality, independence, mutual assistance, and integrity.
\end{abstract}

Keywords: character value, GLN, reading book, elementary school, low-grade

Abstrak : Kementerian Pendidikan dan Kebudayaan meluncurkan buku bacaan non teks untuk anak sekolah dasar tingkatan kelas rendah secara digital dalam situs resmi gln.kemdikbud.go.id. Buku tersebut memuat nilai-nilai karakter sesuai misi bangsa yaitu mencerdasakan siswa secara karakter. Tujuan dari penelitian ini adalah untuk menggambarkan nilai-nilai karakter yang terdapat pada buku bacaan Kementerian Pendidikan dan Kebudayaan kelas rendah dan mendeskripsikan kesesuaian penerapannya menurut Peraturan Menteri dan Kebudayaan Nomor 20 Tahun 2018. Metode penelitian ini adalah deskriptif kualitatif. Nilai karakter dalam buku tersebut ditunjukkan melalui percakapan, tindakan atau jalan pikiran tokoh. Selanjutnya, nilai-nilai tersebut ditandai dan catat. Nilai karakter menurut

http://ejournal.iainbengkulu.ac.id/index.php/disastra

Copyright ( $) 2021$ Disastra: Jurnal Pendidikan Bahasa dan Sastra Indonesia

All rights reserved 
Permendikbud Nomor 20 Tahun 2018 dan Pusat Kurikulum dan Perbukuan digunakan sebagai landasan. Setelah data-data terkumpul, maka data tersebut siap untuk dianalisis. Teknik datanya menggunakan teknik menyimak, mencatat, dan menulis. Hasil penelitian diperoleh 9 nilai pendidikan karakter berupa 23 nilai peduli sosial, 10 nilai kerja keras, 9 nilai keagamaan, 2 nilai toleransi, 1 nilai peduli lingkungan, 1 nilai mandiri, 1 nilai cinta tanah air, 1 nilai tanggung jawab, dan 1 nilai gemar membaca. Nilai ini berkembang dari 5 nilai karakter utama karakter bangsa yang dicanangkan dalam Peraturan Menteri Pendidikan dan Kebudayaan Nomor 20 Tahun 2018 seperti religius, nasionalis, mandiri, gotong royong dan berintegritas.

Kata Kunci: nilai karakter, GLN, buku bacaan, sekolah dasar, kelas rendah

\section{Pendahuluan}

Dalam

penyelenggaraan

pendidikan, pendidikan karakter menjadi salah satu pilar penting. Di Indonesia, pendidikan karakter sangat penting mengingat banyak fenomena-fenomena yang kurang pantas yang menandakan degradasi moral. Pada perkembangannya, yaitu tahun 2009-2010 nilai luhur mengalami perkembangan menjadi nilai karakter. Melalui adanya pendidikan karakter, maka bisa tercetak moral dan kecerdasan akademik yang seimbang. Nilai ketuhanan, nilai pribadi, nilai sosial, serta nilai pengetahuan dan juga lingkungan juga diterapkan dalam pendidikan karakter ini. Sampai kini, guna mengatasi rendahnya nilai moral bangsa ini pendidikan karakter masih sangat diperlukan. Sekolah memikul tanggung jawab untuk menanamkan nilai karakter, sebagai lembaga pendidikan yang formal. Terjadi banyak kasus yang menyiratkan kemerosotan moral yang disebabkan oleh kurangnya pengembangan pada nilai karakter oleh anak usia SD.

Pendidikan karakter hendaknya diterapkan sedini mungkin pada masa keemasan anak, dengan menanamkan nilai dasar karakter yang kelak dimasa depan akan berguna (Triaristina \& Mukhlis,
2019). Menurut Astuti (2017), anak yang berusia 7-13 tahun, dimana ia duduk di bangku kelas rendah yaitu kelas I, kelas II, kelas III mengalami momen penting untuk menanamkan karakter cerdas serta akhlak yang mulia di dunia bangku.

Sekolah dasar inilah, peserta didik memperluas lingkup sosialnya, dari yang semula hanya bergaul dengan lingkup sosial keluarga, hingga bisa meluas mengenal orang sekitar dan lingkungannya (Putri, 2018). Arah perkembangan potensi peserta didik, ditentukan oleh pendidikan yang paling dasar, yaitu secara formal pendidikan sekolah dasar. Atas alasan itulah, maka dalam suatu penyelenggaraan pendidikan sekolah dasar, diajarkan pengembangan karakter (Annisa, 2019). Pada bangku SD inilah, terutama pada kelas rendah dimana merupakan masa keemasan anak untuk diberikan pemahaman nilai karakter dan dilatih menerapkan karakter-karakter tersebut.

Jenis-jenis nilai pendidikan karakter memiliki beberapa versi. Versi nilai pendidikan karakter yang pertama, yaitu jenis nilai karakter yang terdapat dalam Pusat Kurikulum dan Perbukuan, (2011) memuat bahwa nilai pendidikan pendidikan karakter meliputi 18 nilai yaitu religius, rasa ingin tahu, demokratis, gemar 
membaca, peduli lingkungan, peduli sosial, tanggung jawab jujur, toleransi, disiplin, kerja keras, kreatif, mandiri, menghargai prestasi, bersahabat/ komunikatif, cinta damai, semangat kebangsaan, dan cinta tanah air. Agama, Pancasila, budaya dan Tujuan Pendidikan Nasional, menjadi bahan sumber dari turunan 18 nilai pendidikan karakter tersebut. Akan tetapi, nilai pendidikan karakter mengalami pembaruan, yaitu dengan diterbitkannya Permendikbud Nomor 20 Tahun 2018 yang isinya meringkas nilai pendidikan karakter jenisnya menjadi lima saja yaitu nilai religius, nilai nasionalis, nilai integritas, nilai mandiri, dan nilai gotong royong.

Untuk membentuk perilaku siswa yang baik, diperlukan pengembangan nilai karakter. Penanaman nilai karakter peserta didik juga dapat dilakukan dengan mengombinasikan media teknologi. Era teknologi canggih seperti saat ini, kalangan anak-anak maupun dewasa bisa mengakses dan memanfaatkannya (Kusumastuti, N., \& Rukiyati, R. 2017). Manfaat teknologi amat dirasakan bagi dunia pendidikan, termasuk untuk aktivitas literasi. Berbagai lama situs, email ataupun website dapat diakses peserta didik untuk mendapatkan informasi dan pengetahuan. Kendati demikian, adanya pemanfaatan teknologi tersebut bukan berarti bahwa teknologi bisa menggantikan buku paket atau buku teks cetak, melainkan sebagai pelengkap sumber pengetahuan ketika berlangsungnya proses belajar mengajar (Putri, 2018). Untuk itulah, Kemendikbud meluncurkan buku bacaan non teks untuk anak SD tingkatan kelas rendah kelas satu, dua, dan tiga secara digital, dalam situs resmi gln.kemdikbud.go.id. Buku tersebut
Volume 3, Nomor 2, Juli 2021

ISSN 2655-3031 (P), 2655-7851 (O)

DOI: http://dx.doi.org/10.29300/disastra.v3i2.4760

didalamnya memuat nilai-nilai karakter sesuai misi bangsa ini, yaitu mencerdasakan siswa secara karakter juga. Untuk itulah, artikel ini dibuat dengan tujuan untuk menemukan nilai karakter yang ada dalam buku bacaan Kemdikbud kelas rendah, kelas satu, dua dan tiga. Penelitian ini memiliki tujuan untuk 1) memaparkan nilai karakter yang ada dalam buku bacaan Kemdikbud kelas rendah, 2) mendeskripsikan kesesuaian penerapan nilai karakter yang terdapat dalam buku bacaan bacaan Kemdikbud kelas rendah dengan nilai karakter siswa menurut Permendikbud Nomor. 20 Tahun 2018.

Dari latar belakang diatas, maka rumusan masalahnya sebagai berikut, 1) apa saja nilai karakter yang ada dalam buku bacaan Kemdikbud kelas rendah?, 2) bagaimana kesesuaian penerapan nilai karakter yang terdapat dalam buku bacaaan Kemdikbud kelas rendah dengan nilai karakter siswa menurut Peraturan Menteri Pendidikan dan Kebudayaan Nomor. 20 Tahun 2018?. Dari rumusan masalah tersebut, maka penelitian ini bertujuan untuk 1) mendeskripsikan nilai karakter yang ada dalam buku bacaan Kemdikbud kelas rendah, 2) mendeskripsikan kesesuaian penerapan nilai karakter yang terdapat dalam buku bacaan Kemdikbud kelas rendah dengan nilai karakter siswa menurut Peraturan Menteri Pendidikan dan Kebudayaan Nomor. 20 Tahun 2018. Manfaat penelitian ini adalah dengan temuan data nilai karakter dalam buku bacaan kelas rendah Kemdikbud pada situs gln.kemdikbud.go.id maka bisa menjadi rujukan dan perbaikan kedepannya, melengkapi nilai-nilai karakter yang belum termuat dalam buku bacaan tersebut. 
Penelitian sebelumnya yang menjadi rujukan yaitu penelitian yang dilakukan oleh Jannah, dkk (2019), dimana penelitiannya yang berjudul Analisis NilaiNilai Karakter Hasil Karya Menulis Kreatif Siswa, menggunakan analisis secara deskriptif kualitatif dan hasilnya menunjukkan bahwa dalam objek kajiannya yaitu karya siswa menulis cerita, ada lima nilai karakter yang tekandung, yaitu nilai peduli sosial, nilai cinta damai, nilai bersahabat/komunikatif, nilai kerja keras, dan nilai kreatif. Perbedaan penelitian ini dengan penelitian Jannah, dkk (2019) adalah terletak pada objek kajiannya. Jika pada penelitian ini, yang menjadi objek kajian nilai karakter yang diteliti adalah buku bacaan GLN Kemdikbud kelas rendah SD, sedangkan pada penelitian Jannah, dkk (2019) objek kajian yang diteliti yaitu karya siswa dalam menulis cerita.

Selain penelitian Jannah (2019) penelitian sebelumnya yang dijadikan rujukan yaitu penelitian yang dilakukan Efendi (2020) yang berjudul Nilai Karakter dalam Novel Biografi Hatta: Aku Datang karena Sejarah Karya Sergius Sutanto. Hasil penelitiannya menunjukkan bahwa Novel Biografi Hatta: Aku Datang karena Sejarah karya Sergius Sutanto memiliki enam nilai pendidikan karakter yaitu semangat kebangsaan, cinta tanah air, cinta damai, mandiri, jujur, dan gemar membaca. Hasil penelitian ini yang berikutnya, yaitu mengenai bagaimana cara pengeskpresian Fokus penelitian Efendi adalah meneliti nilai karakter utama dan cara pengekspresian karakter dalam Novel Biografi Hatta: Aku Datang karena Sejarah karya Sergius Sutanto. Sedangkan fokus penelitian saya yaitu nilai karakter dalam
Volume 3, Nomor 2, Juli 2021

ISSN 2655-3031 (P), 2655-7851 (O)

DOI: http://dx.doi.org/10.29300/disastra.v3i2.4760

buku bacaan GLN Kemdikbud kelas rendah, kelas satu, dua dan tiga.

\section{Metode Penelitian}

Metode kualitatif deskriptif digunakan dalam penelitian ini. Teknik simak, catat, dan tulis digunakan sebagai pengumpulan data. Pertama-tama, penulis membaca seluruh buku-buku bacaan kelas rendah (kelas satu, dua, dan tiga) SD yang ada dalam situs gln.kemdikbud.go.id. Buku bacaan berformat digital tersebut lalu kami baca dan disimak, sekaligus ketika membaca lalu menemukan nilai karakter yang ada pada buku tersebut, baik itu melalui percakapan tokoh, tindakan ataupun jalan pikiran tokoh, maka bagian yang menunjukkan nilai karakter tersebut kami tandai dan catat. Nilai karakter yang menjadi patokan yaitu nilai karakter menurut Permendikbud Setelah data-data terkumpul, maka data tersebut siap untuk dianalisis. Adapun objek penelitian ini adalah buku bacaan Gerakan Literasi Nasional (GLN) Kementerian Pendidikan dan Kebudayaan yang ada pada situs gln.kemdikbud.go.id, yaitu buku berjudul Jangan Ambil Rumah Kami karya Erminawati ND, Cerpen dan Dongeng Minuman Nusantara, Arsitektur Nusantara karya Komunitas Omah Aksara, dan Berguru kepada Anak Laut Suku Bajo karya Harjani Mustika D.

\section{Hasil dan Pembahasan}

Nilai karakter yang terdapat dalam buku berupa nilai kasih sayang, nilai religious, nilai budaya, nilai kerja keras, nilai kepedulian, nilai toleransi, nilai gotong royong, sebagai berikut. 


\section{Nilai Peduli Sosial}

Nilai peduli sosial yang terdapat dalam buku bacaan GLN Kemdikbud kelas rendah (kelas 1, 2 dan 3 Sekolah Dasar) dengan 23 contoh data sebagai berikut.

(1) ... sebagai saudara se-Sriwijaya, mana mungkin kubiarkan saudaraku menderita (Arsitektur Nusantara 2017: 16).

(2) “... selayaknya kita saling tolongmenolong,"

kata

Gadang...(Arsitektur Nusantara 2017:

17).

(3) ... semakin tambah banyak warga desa yang datang membantu ... (Arsitektur Nusantara 2017: 27).

(4) Esoknya, ketika ... warga desa datang. Mereka iba dan ingin membantu membangun rumah Nawangsih. (Arsitektur Nusantara 2017: 27).

(5) “... Wawai sambil mengelus-elus kepala anak anjing hutan yang dinamainya Kiko. (Arsitektur Nusantara 2017: 42)

(6) Sambil menyerahkan ikan, Wawai mengelus-elus kepala Kiko (Arsitektur Nusantara 2017: 45).

(7) Naluri binatang Kiko merasakan kebaikan dan ketulusan Wawai ... Ia terlihat menikmati elusan di kepalanya (Arsitektur Nusantara 2017: 45).

(8) ... "Dengar 'kan, Kiko? Kamu sudah menjadi keluarga kami." (Arsitektur Nusantara 2017: 47).

(9) “ ... Dilihatnya bayi laki-laki... Pak Eku merasa kasihan ... (Cerpen dan Dongeng Minuman Nusantara 2017: $1)$.

(10) ... Raja Seberang segera memeluk Ranu sambil menangis bahagia ..." (Cerpen dan Dongeng Minuman Nusantara 2017: 6).
Volume 3, Nomor 2, Juli 2021

ISSN 2655-3031 (P), 2655-7851 (O)

DOI: http://dx.doi.org/10.29300/disastra.v3i2.4760

(11) “... Deka merasa iba ... Deka segera menuntun nenek itu ... (Cerpen dan Dongeng Minuman Nusantara 2017: 16).

(12)Dengan suara lembut, Mama... menggosokkan minyak angin ke perut dan punggung anak kesayangannya (Cerpen dan Dongeng Minuman Nusantara 2017: 26).

(13) "Hmmm, kasihan Moci..." (Cerpen dan Dongeng Minuman Nusantara 2017: 34).

(14) "Aku harus menolongnya," ... (Cerpen dan Dongeng Minuman Nusantara 2017: 34).

(15) “Jangan!... Jangan sakiti Moci!” ... (Cerpen dan Dongeng Minuman Nusantara 2017: 35).

(16) “ ... Anak Indonesia sudah seharusnya bisa berenang," bapak mengelus kepala Kaloko (Berguru pada anak Suku Laut Bajo 2017: 8).

(17) “... menolong dan bergotongroyong ... tetangga langsung membantu (Jangan Ambil Rumah Kami, 2017: 6)

(18) “... kata ibuku sambil memelukku dengan kasih sayang (Jangan Ambil Rumah Kami, 2017:14)

(19) “...Pita tolong sebarkan berita ini ke teman-teman kita," kata angin ..(Jangan Ambil Rumah Kami, 2017: 19).

(20) ... Ibu sangat menyayangimu," ibuku berkata lirih (Jangan Ambil Rumah Kami, 2017:42).

(21) Pikiranku masih tertuju kepada ibuku ... "nanti kita cari tahu di mana ibumu berada," hibur ... (Jangan Ambil Rumah Kami, 2017: 45).

(22) “... Sudahlah ...nanti kita cari tahu di mana ibumu berada," hibur Tati (Jangan Ambil Rumah Kami, 2017:45).

Winda Dwi Lestari, Atiqa Sabardila

Menguak Nilai Pendidikan Karakter Buku Bacaan Gerakan Literasi Nasional Kementerian Pendidikan dan Kebudayaan Kelas Rendah Sekolah Dasar 
(23)... Fika merawat ibuku sampai sembuh (Jangan Ambil Rumah Kami, 2017:46).

Nilai peduli sosial menjadi nilai yang dominan dalan buku bacaan GLN Kemdikbud untuk anak SD kelas rendah dengan 23 contoh. Nilai peduli sosial sebagaimana menurut Marsudi (2020) merupakan sikap dan tindakan yang selalu ingin memberi bantuan kepada orang lain dan masyarakat yang membutuhkan. Pada data 1, ucapan tokoh tak akan kubiarkan saudaraku menderita, menunjukkan bahwa ada kepedulian sosial.

Data (1), menggambarkan nilai kepedulian sosial dimana tokoh Nowou Sesat mengucapkan kalimat bahwa ia tak akan membiarkan saudara lainnya menderita. Hal itu dapat dijadikan sarana menamkan nilai kepedulian bagi siswa, bahwasanya jika ada saudara yang menderita atau kesusahan, kita harus peduli dan menolongnya. Sebagaimana dikemukakan oleh (Admizal \& Fitri, 2018), kepedulian merupakan tindakan, bukan hanya pemikiran atau perasaan saja, juga mau melakukan gerakan walaupun kecil.

Pada contoh (2), adanya kalimat kita harus saling tolong menolong menunjukkan bahwasanya sebagai makhluk Tuhan hendaknya memiliki kepedulian sosial dengan cara saling tolong-menolong. Berikutnya, pada contoh (3), nilai kepedulian sosial digambarkan dengan banyaknya warga yang berdatangan untuk membantu. Nilai peduli sosial juga ditunjukkan pada contoh (4), yang mana diceritakan bahwa para tetangga berdatangan untuk gotong royong, iba melihat kondisi rumah Nawangsih yang rusak.
Volume 3, Nomor 2, Juli 2021

ISSN 2655-3031 (P), 2655-7851 (O)

DOI: http://dx.doi.org/10.29300/disastra.v3i2.4760

Nilai kepedulian sosial tidak hanya menjurus pada nilai peduli sosial terhadap sesama manusia saja, melainkan peduli sosial terhadap makhluk Tuhan yang lain, yaitu binatang. Pada contoh (5), (6), (7), dan (8), mengajarkan kepedulian sosial terhadap hewan. Tindakan mengelus-elus binatang, merawat hewan sepenuh hati, menyiratkan kasih sayang sebagai pertanda bahwa ia memiliki kepedulian sosial.

Nilai peduli sosial lebih menjurus ke nilai kasih sayang, sesuai dengan karakter anak usia kelas satu, dua dan tiga SD paling banyak termuat, sesuai dengan karakter anak usia kelas rendah SD, mengenalkan dan menanamkan nilai kasih sayang. Pada data (1) sampai dengan data (23) menunjukkan nilai peduli sosial berupa kasih sayang, melalui tindakan yang dilakukan oleh tokoh, ataupun melalui kalimat yang diucapkan oleh tokoh ataupun dialog antar tokoh tersebut. Sebagaimana menurut Nurgiyantoro (2010), pada suatu cerita, terdapat suatu karakter praktis yang dapat dipetik nilai karakternya oleh pembaca itu sendiri. Sehingga, pembaca dengan membaca cerita tersebut dapat mengambil pelajaran dari itu. Pembaca, diharapkan untuk bisa mengambil nilai karakter dari sikap, perilaku maupun tuturan dialog tokoh dalam buku. Jika baik maka akan ditiru, dan jika buruk akan dihindari atau tidak ditiru Sehingga nilai kasih sayang termuat tidak hanya eksplisit namun juga inplisit tersirat dari tindakan tokoh. Menurut Triaristina, Aprlia dan Mukhlis (2019), nilai tersebut kemudian dapat dirasakan (moral feeling) dan dibiasakan pada anak (moral actions).

Nilai kasih sayang berhubungan dengan keharmonisan, dimana terdapat ungkapan 
atau menunjukkan perasaan kasih sayang, lembut, sehingga ada jalinan rasa saling melindungi satu sama lain (Ummi \& Mulyaningsih, 2017). Nilai pendidikan karakter kasih sayang misalnya ditunjukkan oleh tindakan tokoh Kiko yang mengeluselus kepala anak anjing hutan. Selain itu, nilai pendidikan karakter juga ditunjukkan secara eksplisit melalui kalimat yang diucapkan oleh tokoh, yaitu tokoh Kiko mengucapkan kasihan sekali. Pasti ia merasa sangat kehilangan. Sehingga, pembaca yang merupakan anak SD kelas rendah dapat memetik nilai tersebut, bahwa terhadap hewan kita haruslah saling menyayangi, dan memperlakukannya dengan baik. Pada data (8) nilai kasih sayang ditunjukkan dengan perkataan tokoh Kiko yang mengatakan ".. kamu sudah menjadi keluarga kami”.

Nilai kepedulian ditunjukkan pada pada contoh (10), kasih sayang ditunjukkan melalui tindakan tokoh yang memeluk. Data (11) dan (14), menunjukkan bahwa kepedulian dengan cara menolong orang yang sedang membutuhkan pertolongan, setelah melihat ia merasa iba dan timbul rasa empati. Rasa itulah yang menunjukkan bahwa karakter pada cerita tersebut memiliki kepedulian sosial. Tindakan kasih sayang dengan mengelus kepala juga terdapat lagi dalam data (16), dimana seorang Bapak mengelus kepala anaknya dengan lembut, mengisyaratkan kasih sayang antara orang tua atau bapak dengan anak. Tindakan kasih sayang orang tua terhadap anak juga ditunjukkan pada data nomor (20) dimana menunjukkan kasih sayang antara ibu dengan anak, dengan mengucapkan sayang, secara eskplisit menyatakan sayang kepada anaknya. Pada
Volume 3, Nomor 2, Juli 2021

ISSN 2655-3031 (P), 2655-7851 (O)

DOI: http://dx.doi.org/10.29300/disastra.v3i2.4760

data (20), kepedulian sosial tidak ditunjukkan langsung dalam kalimat, melainkan ditunjukkan secara langsung, secara eksplisit disebutkan bahwa masyarakat desa suka bergotong royong. Taka ada rasa pamrih, melainkan penuh dengan rasa ikhlas serta tulus untuk membantu dengan melakukannya secara bersama-sama (Utomo, 2018). Dalam buku bacaan tersebut, diceritakan warga bergotong royong membantu warga yang kesulitan yang artinya mereka memiliki kepedulian sosial.

Nilai kepedulian dengan cara menghibur teman yang sedih terdapat dalam data (21) dan (22). Pada data (21), terdapat tindakan tokoh untuk menghibur temannya yang bersedih karena berpisah dengan ibunya. Selain iba, menghibur temannya agar tidak bersedih, temannya juga menawarkan diri membantu ia mencari ibunya. Pada contoh (23), nilai kepedulian sosial berupa kasih sayang seorang anak yang merawat induk burung dengan baik. Hal ini mengajarkan kepada pembaca yaitu anak-anak agar menyayangi hewan. Senada dengan data nomor (5), (6), dan (7) yang pada intinya kita harus menyayangi hewan, tidak menyakitinya. Karakter kasih sayang yaitu karakter dimana ada perasaan suka, saling menyayangi, dan simpati terhadap sesuatu dengan sepenuh hati (Fajriniski et al., 2018).

\section{Nilai Kerja Keras:}

(24) ... lakukan sebisamu. ... Ayo semangat!" ... (Arsitektur Nusantara 2017: 52).

(25) Sawa mencoba lagi, ... Bulir keringat tampak turun mengaliri pipinya ... (Arsitektur Nusantara 2017: 53) 
(26) ... Esoknya, Sawa masih belajar lagi ... (Arsitektur Nusantara 2017: 53)

(27) ... Semangat belajarnya masih sama dengan kemarin.... (Arsitektur Nusantara 2017: 53).

(28) ... tenaga Sawa sudah habis ... (Arsitektur Nusantara 2017: 53).

(29) ... aku tidak boleh gagal," batin Deka bersemangat ..." (Cerpen dan Dongeng Minuman Nusantara 2017: 21).

(30) Bapak pernah bercerita perjuangannya ... bagaimana sulitnya mencapai puncak, ... (Berguru pada anak Suku Laut Bajo 2017: 11).

(31) Di sekolah, Azka merasa lebih bergairah. Dia memilih duduk paling depan ... (Cerpen dan Dongeng Minuman Nusantara 2017: 27).

(32) "Cepat, Tika! ... "Iya, tunggu. Pasti aku akan naik hingga ke puncak menara." (Cerpen dan Dongeng Minuman Nusantara 2017: 47).

(33) Jirin harus jauh-jauh ke pulau tetangganya hanya untuk berkirim kabar ... (Berguru pada anak Suku Laut Bajo 2017: 39).

Dalam buku bacaan GLN kelas rendah, terdapat nilai karakter kerja keras yaitu ditunjukkan sejumlah sepuluh contoh. Kerja keras merupakan perilaku serta tindakan sungguh-sungguh yang dilakukan oleh seseorang, serta bisa menyelesaikan problematika dengan sangat baik, yang bisa saja muncul ketika mengerjakan suatu hal (Irma, 2018). Dari data (24) sampai dengan (28) terdapat rangkaian tindakan dan pola pikir untuk bekerja keras pada tokoh Sawa. Tokoh Sawa yang mulanya payah dalam membuat sarang laba-laba, berkat motivasi
Volume 3, Nomor 2, Juli 2021

ISSN 2655-3031 (P), 2655-7851 (O)

DOI: http://dx.doi.org/10.29300/disastra.v3i2.4760

ayahnya dan berbekal kerja keras, ia akhirnya bisa meraih tujuannya. Nilai karakter kerja keras juga ditunjukkan pada data (29) dimana tokoh Deka bertekad tidak mau gagal dalam ujian sehingga ia bersemangat dalam ujian. Deka yang tidak ingin gagal saat ujian memilih untuk lebih bersemangat saat ujian, menandakan bahwa ia benar-benar bekerja keras agar ia tidak gagal ketika ujian. Pada data (40) secara naratif juga ditunjukkan nilai karakter kerja keras, yaitu dimana penulis menceritakan tokoh Bapak yang masa mudanya bekerja keras, mendaki gunung dengan berlelahlelah terlebih dahulu namun pada akhirnya dapat sampai tujuan puncak, walaupun perjalannya berat. Cerita tokoh Bapak tersebut menggambarkan bagaimana kerja kerasnya beliau ketika masih muda. Semanagat dan kerja kerasnya, bagi pembaca anak SD kelas I, II, dan III dapat diteladani.

Nilai kerja keras juga ditunjukkkan pada data (31) sampai dengan (33). Pada data (31), kerja keras ditunjukkan dengan menceritakan tokoh Azka yang lebih bergairah ketika di sekolah, duduknya paling depan, mendengarkan penjelasan dengan seksama. Azka bekerja keras untuk menuntut ilmu, ditunjukkan melalui kesungguhannya dalam menuntut ilmu di sekolah.

Selain itu, nilai kerja keras juga ditunjukkan oleh tokoh Hana pada data (32) yang mengatakan bahwa ia pasti akan sampai ke puncak tujuannya. Dengan teriakan tersebut, ia seolah menggambarkan bahwa ia sedang benar-benar bekerja keras untuk mencapai tujuannya itu, untuk mencapai puncak menara. Nilai kerja keras yang terakhir, yaitu pada data (33) yang 
menunjukkan jika Jirin harus bekerja keras untuk mendapatkan sinyal guna berkirim kabar melalui telepon genggam. Untuk mendapatkan sinyal, ia harus menempuh perjalanan jauh ke pulau tetangga. Hal ini secara tidak langsung menyiratkan bahwa tanpa ada kerja keras atau usaha dari Jirin untuk ke Pulau lain mencari sinyal, maka Jirin tidak akan bisa berkirim kabar. Keterbatasan sinyal itulah yang menjadi penghambat Jirin untuk berkirim kabar. Namun menghadapi hambatan tersebut, Jirin tidak pantang menyerah begitu saja. Ia rela bekerja keras mencari sinyal jauh-jauh ke Pulau. Dari membaca cerita Jirin tersebut, pembaca yang merupakan anak SD kelas I, II, dan III pada akhirnya akan tahu dan mengerti bahwa untuk mencapai tujuan, haruslah dengan usaha yang keras pula, walaupun ada rintangan. Pembaca akan memetik nilai kerja keras setelah membaca bagian cerita Berguru Kepada Anak Laut Suku Bajo melalui tindakan tokoh Jirin tersebut dalam menghadapi keterbatasan sinyal untuk berkomunikasi. Sebagaimana dijelaskan oleh Marsudi, dkk (2020), kerja keras merupakan perilaku yang menunjukkan upaya sungguh-sungguh dalam mengatasi berbagai hambatan ketika belajar atau mengerjakan sesuatu. Tindakan tokoh Jirin yang harus ke Pulau untuk mencari sinyal, menandakan bahwa Jirin memiliki karakter kerja keras, untuk mengatasi hambatan sinyal ketika hendak berkomunikasi menggunakan jaringan.

\section{Nilai Religius}

(34) “... berdoa kepada Tuhan agar ayahnya baik ..." (Arsitektur Nusantara 2017: 25).
Volume 3, Nomor 2, Juli 2021

ISSN 2655-3031 (P), 2655-7851 (O)

DOI: http://dx.doi.org/10.29300/disastra.v3i2.4760
"Duh Gusti ... Ampuni hamba, Gusti!" (Arsitektur Nusantara 2017: 27).

“... karomah, yaitu menjawab salam ayahnya saat ibunya sedang sholat." (Arsitektur Nusantara 2017: 35).

"Subhanallah," ucap Sepoi terkagum-kagum. (Arsitektur Nusantara 2017: 35).

“... keagungan dan keindahan hidup ini tidak akan mengikuti kita sampai ke dalam liang lahat ... (Arsitektur Nusantara 2017: 35)

"Maka alangkah lebih baik, ... beribadah dan saling membantu sesama makhluk Tuhan." (Arsitektur Nusantara 2017: 35).

"Hana, Tika, ayo salat subuh dulu!" ... (Ziarah ke Tanah Jawa, 2017:29).

"...kita tidak boleh meminta pertolongan kepada selain Allah, termasuk melalui perantara jin ... " (Ziarah ke Tanah Jawa, 2017:44).

"Makanlah sesudah lapar dan berhentilah sebelum kenyang ..."(Ziarah ke Tanah Jawa, 2017:44).

Nilai karakter religius yang ditemukan dalam buku bacaan GLN kelas rendah ada sembilan. Nilai religius berupa doa ditemukan dalam buku berjudul Arsitektur Nusantara, ditunjukkan pada data (34) dimana tokoh anak berdoa kepada Tuhannya ditengah-tengah kondisinya yang sedang sakit. Sang anak berdoa agar ayahnya diberikan watak yang lebih baik. Adanya tindakan tokoh untuk berdoa, mengajarkan pada anak akan karakter religius. Doa, menandakan bahwa ada nilai religius atau keyakinan kepada Tuhannya 
dengan memohon kepada-Nya. Pada data (35), nilai religius ditunjukkan dengan tokoh mengucapkan “.. duh Gusti.." dan tindakannya yang berdoa memohon ampun kepada Gusti atau Tuhannya, menunjukkan bahwasanya anak diajarkan untuk berdoa, meminta ampunan pada Gusti atau Tuhannya agar diampuni segala kesalahannya. Pada data (36) terdapat penggunaan istilah karomah, ajakan dan petuah tentang sholat, penyebutan asma Allah oleh tokoh. Kata-kata tersebut menyiratkan nilai religius. Contoh lainnya, misalnya kata Subhanallah pada data (37).

Pada temuan (37), terdapat nilai karakter religius yang diajarkan, yang ditunjukkan oleh tokoh Sepoi yang mengucapkan kalimat tasbih Subhanallah, ketika takjub terhadap sesuatu yang ia rasakan atau ia lihat. Dalam ajaran agama Islam, jika melihat sesuatu yang menakjubkan maka dianjurkan untuk mengucap Subhanallah. Hal ini akan membuat anak menjadi paham bahwasanya ketika ia mendapati sesuatu yang membuat ia takjub, maka akan mengucap Subhanallah.

Pada contoh (38) dan (39), nilai religi ditunjukkan pada kalimat wejangan bahwasanya hidup ini tak akan abadi, sehingga kita hendaknya memeprgunakan hidup dengan sebaik-baiknya, mengisi hidup dengan ibadah dan membantu orang lain.

Pada data (40), nilai religius ditunjukkan dengan tindakan tokoh untuk mengajak tokoh lain untuk sholat Subuh. Kemudian, pada data (41) terdapat nilai religius yang dimuat yaitu ajaran untuk tidak menyekutukan Tuhan. Selanjutnya, penyebutan hadist Nabi Muhammad SAW
Volume 3, Nomor 2, Juli 2021

ISSN 2655-3031 (P), 2655-7851 (O)

DOI: http://dx.doi.org/10.29300/disastra.v3i2.4760

pada data (42) menunjukkan bahwa diselipkan nilai religius dalam buku tersebut, agar dapat dipahami dan diteladani oleh anak bahwasanya ketika makan kita tidak boleh terlalu kenyang, sesuai dengan hadist Nabi tersebut. Nilai karakter religius sebagaimana dikemukakan oleh (Mushfi et al., 2019), karakter religius akan menjadikan seseorang berakhlak mulia (Ummi \& Mulyaningsih, 2017). Nilai religius menunjukkan bahwa seseorang yang mempunyai keimanan. Sebagaimana menurut Marsudi, dkk (2020), seseorang yang melaksanakan ajaran sesuai apa yang dianutnya dan juga dapat hidup rukun dengan pemeluk agama lain. Tindakan, perilaku dan dialog tokoh diatas mencerminkan adanya nilai religius.

\section{Nilai Toleransi:}

(43) ... Dia seharusnya tidak marah saat minumannya habis ... Jika Sita yang lebih kecil darinya mau berbagi, mengapa Rere tidak?

(44) ... saling mengerti dan tidak egois ... menghargai dan menghormati satu sama lain ... (Ziarah ke tanah Jawara 2017: 38).

Nilai toleransi ditunjukkan oleh data (43), dimana dalam potongan cerita itu, dinarasikan oleh penulis bahwa tokoh Rere merasa malu dan tersadar bahwa tindakannya yang marah ketika minumannya dihabiskan oleh saudaranya adalah tidak baik, karena seharusnya ia bisa memaklumi dan mentoleransi, bahwa saudaranya mengabiskan minumannya karena belum pernah mencicipi minuman tersebut, atau jarang menemukan minuman tersebut karena lokasinya berada di pelosok desa. Sehingga, digambarkan penyesalan 
tokoh Rere yang tidak mau mengalah dan marah saat minumannya dihabiskan oleh saudaranya, padahal dibalik itu seharusnya Rere memberikan toleransi, memaklumi mereka begitu karena jarang menemukan minuman kesukannya tersebut. Pada contoh (44), nilai toleransi nampak jelas melalui kalimat saling mengert, tidak egois, menghormati satu sama lain. Jika dikaitkan dengan definisi toleransi menurut Marsudi, dkk (2020), yang menyebutkan bahwa toleransi merupakan sikap saling menghargai akan adanya perbedaan baik perbedaan suku, agama, pandangan, suku, etnis, budaya, sikap orang lain yang berbeda-beda, maka dari 2 temuan data tersebut menunjukkan toleransi dengan menghargai sikap dan tindakan orang lain.

\section{Nilai Peduli lingkungan}

(45) ... Tetapi, janganlah ubah kebaikan hati kalian. Jagalah alam dengan baik ... (Jangan Ambil Rumah Kami, 2017:50).

Pada data (45) peduli lingkungan ditunjukkan melalui kalimat yang diucapkan secara monolog oleh tokoh dalam cerita tersebut. Jagalah alam dengan cara yang baik, dan diimbuhi dengan katakata manusia bersifat baik, menunjukkan bahwa penulis berupaya untuk menanamkan nilai kepedulian terhadap lingkungan, untuk menjaga alam dengan baik. Sebagaimana menurut Marsudi, dkk (2020), bahwa peduli lingkungan merupakan sikap cinta lingkungan, mencegah kerusakan alam dan berupaya memperbaiki kerusakankerusakan yang terjadi. Ucapan tokoh pada buku Jangan Ambil Rumah Kami, menunjukkan bahwa ia berupaya
Volume 3, Nomor 2, Juli 2021

ISSN 2655-3031 (P), 2655-7851 (O)

DOI: http://dx.doi.org/10.29300/disastra.v3i2.4760

menghimbau agar menjaga alam dengan baik.

\section{Nilai Mandiri}

(46) "Harus mandiri ... belajar untuk menyiapkan segala sesuatunya sendiri. Cuci piring dan bajumu sendiri ya, ..." (Ziarah ke tanah Jawara 2017:2).

Nilai mandiri terdapat dalam buku bacaan, yaitu pada data (46) secara jelas tokoh Bunda memberikan petuah kepada putrinya, yang bernama Cantika agar bisa mandiri, mengerjakan segala sesuatu sendiri, misalnya mencuci piring dan bajunya sendiri. Bunda dari Tokoh Cantika memeri nasihat kepada putrinya bahwa ia harus bisa menyelesaikan pekerjaanpekerjaanya tanpa bergantung pada orang lain. Sebagaimana menurut Marsudi (2020), mandiri yaitu sikap dan perilaku yang tidak mudah tergantung kepada orang lain dalam menyelesaikan tugas-tugasnya. Hal ini akan akan mendidik siswa agar mandiri juga. mandiri, tindakan seseorang yang mampu mengerjakan sesuatu tanpa harus menyusahkan orang lain (Putri FP \& Afnita, 2020). Dengan membaca bagian tersebut, siswa akan menjadi paham dan berkeinginan untuk mandiri. Apalagi untuk anak usia kelas rendah yang masih duduk dibangku kelas I, II dan III SD. SD adalah masa pembentukan sikap kemandirian, mulai dilatih untuk mengerjakan kebutuhan pribadinya secara mandiri, sebagaimana disebutkan oleh tokoh Bunda yang memberikan nasihat pada Cantika agar mandiri mencuci piring dan bajunya sendiri. Tindakan tokoh tersebut sesuai dengan menurut (Purawinangun, 2020) yaitu merupakan sikap, perbuatan dan perilaku yang membuat anak percaya diri untuk 
melakukan segala sesuatu sendiri, tanpa bergantung kepada orang lain.

\section{Nilai Cinta Tanah Air:}

(47) Aku bangga dilahirkan sebagai anak Indonesia (Ziarah ke Tanah Jawa, 2017:41).

Nilai karakter berikutnya, yaitu nilai cinta tanah air. Dalam data (47) disebutkan bahwa si tokoh mengucapkan bahwa ia bangga Indonesia merupakan tempat kelahirannya, yang otomatis membuat ia menjadi anak yang tempat kelahirannya di Indonesia. Sebagaimana menurut (Aisyah \& Wulandari, 2018), cara berfikir dan tingkah laku yang menjunjung tinggi dan bangga kepada poleksosbud bangsa, merupakan bentuk nasionalisme, cinta tanah air. Pada konteks ini, tokoh $A k u$ cinta dan bangga terhadap bangsa Indonesia, menjunjung tinggi lingkungan fisiknya yaitu negara dimana ia lahir, yaitu Indonesia. Didukung pula dengan pendapat Marsudi, dkk (2020), bahwa cinta tanah air merupakan suatu perspektif, sikap dan perilaku yang mencerminkan sikap setia, peduli, dan bangga terhadap aspek-aspek bangsa (bahasa, budaya, sosial, dan sebagainya).

\section{Nilai Tanggung Jawab:}

(48) ... anak yang rajin. Setiap hari ... membantu Pak Eku ... (Cerpen dan Dongeng Minuman Nusantara 2017: 2).

Nilai tanggung jawab ditunjukkan oleh anak tersebut dengan rajin membantu orang tuanya. Tindakan tersebut menunjukkan bahwa anak tersebut melaksanakan tanggung jawabnya untuk berbakti kepada orang tua, dengam rajin membantu Pak Eku, selaku ayahnya. Sebagaimana menurut
Volume 3, Nomor 2, Juli 2021

ISSN 2655-3031 (P), 2655-7851 (O)

DOI: http://dx.doi.org/10.29300/disastra.v3i2.4760

Pusat Kurikulum dalam Hartono (2014) dijelaskan bahwa tanggung jawab adalah hal wajib yang diperbuat oleh seseorang sebagai bentuk perilaku. Membantu orang tua merupakan salah satu bentuk tanggung jawab anak kepada orang tuanya. Sebagaimana menurut Marsudi, dkk (2020), menjelaskan bahwa tanggung jawab tercermin dengan melaksanakan apa yang sudah menjadi tugas dan kewajibannya. Tugas dan kewajiban tersebut bukan hanya untuk dirinya sendiri, melainkan juga untuk masyarakat luas (lingkungan sosial budaya, bangsa, negara, serta Tuhan Yang Maha Esa).

\section{Nilai Gemar Membaca}

(49) ... Azka juga mempunyai jadwal membaca buku... (Cerpen dan Dongeng Minuman Nusantara 2017: 27).

Nilai gemar membaca menurut Marsudi, dkk (2020) dicerminkan dengan adanya waktu luang untuk membaca buku bacaan yang membawa nilai poisitif atau kebajikan bagi dirinya. Pada data (49), yang menceritakan kebiasaan tokoh Azka yang pada malam hari belajar, tidak suka menonton televisi, dan ketika libur ia mengisi masa liburnya dengan membaca buku. Nilai gemar membaca ditunjukkan oleh tokoh Azka yang diceritakan bahwa ia memiliki jadwal membaca buku, menandakan bahwa ia memiliki kecintaan terhadap buku dan gemar membaca. 
Kesesuaian Nilai Karakter yang Termuat dalam Buku Bacaan GLN Kemdikbud Kelas Rendah dengan Nilai Karakter Siswa Menurut Permendikbud No. 20 Tahun 2018

Dari nilai-nilai karakter yang sudah diuraikan diatas, diantaranya ada 9 nilai yaitu nilai peduli sosial, nilai kerja keras, nilai religius, nilai toleransi, nilai peduli lingkungan, nilai mandiri, nilai cinta tanah air, nilai tanggung jawab, nilai gemar membaca yang masing-masing memiliki banyak contoh dalam buku bacaan. Misalnya nilai kasih sayang yang mendominasi dalam buku, yaitu sebanyak 23. Disusul juga dengan nilai-nilai lainnya. Dimana pada nilai peduli lingkungan, mandiri, cinta tanah air, tanggung jawab, dan gemar membaca jumlahnya masingmasing barulah satu contoh. Apabila peneliti melakukan perbandingan dengan nilai karakter yang termuat pada Permendikbud No. 20 Tahun 2018, maka terdapat perbedaan yakni tidak adanya penerapan nilai integritas dalam buku bacaan GLN tersebut. Kemudian untuk contoh nilai nasionalisme juga masih belum banyak ditemukan dalam buku bacaaan GLN kelas rendah tersebut. Peraturan Mendikbud Nomor 20 Tahun 2018 memuat nilai karakter sopan, mandiri, santun, nasionalisme, religius, integritas, mandiri, dan gotong royong, yang dapat masuk dalam aspek kemampuan sikap, baik itu sikap kerohanian maupun sikap sosial (Hutama, dkk 2019).

\section{Simpulan}

Terdapat dua simpulan dari pemaparan hasil penelitian diatas. Dalam buku GLN Kemdikbud, terdapat 9 nilai pendidikan karakter yaitu nilai peduli sosial, nilai kerja keras, nilai religius, nilai toleransi, nilai peduli lingkungan, nilai mandiri, nilai cinta tanah air, nilai tanggung jawab, nilai gemar membaca, dengan rincian sebagai berikut. 1) 23 Nilai peduli sosial, 2) 10 nilai kerja keras, 3$) 9$ nilai religius, 4) 2 nilai toleransi, 5) 1 nilai peduli lingkungan, 6) 1 nilai mandiri, 7) 1 nilai cinta tanah air, 8) 1 nilai tanggung jawab, dan 9) nilai gemar membaca. Nilai ini mengalami pengembangan dari 5 nilai karakter utama karakter bangsa yaitu nilai integritas, religius, gotong royong, mandiri dan nasionalis. yang dicanangkan oleh Kemdikbud melalui Permendikbud Nomor 20 Tahun 2018. Kaitannya dengan kesesuaian antara nilai karakter yang termuat dalam buku bacaan GLN kelas rendah, dengan nilai karakter menurut Permendikbud No. 20 Tahun 2018, maka diperoleh perbandingan berikut. Dalam buku GLN kelas rendah ini, nilai peduli lingkungan, mandiri, cinta tanah air, tanggung jawab, dan gemar membaca jumlahnya masih sedikit. Nilai intregitas juga tidak muncul dalam buku GLN kelas rendah ini. Untuk itu, besar harapannya penelitian ini dijadikan referensi atau rujukan bagi pihak-pihak yang terkait, guna perbaikan buku kedepannya. Sehingga nilai karakter bangsa dapat dipelajari dan diterapkan secara lengkap oleh siswa khususnya kelas rendah SD, agar tercapai tujuan bangsa yaitu bangsa yang berkarakter dan berakhlak mulia. 
Daftar Pustaka

Admizal, A., \& Fitri, E. (2018). Pendidikan Nilai Kepedulian Sosial pada Siswa Kelas V Di Sekolah Dasar. Jurnal Gentala Pendidikan Dasar, 3(1), 163-180.

https://doi.org/10.22437/gentala.v3i 1.6778

Aisyah, E. N., \& Wulandari, R. T. (2018). Internalisasi Nilai Karakter Nasionalisme melalui Dongeng dan Tari (DORI) bagi Anak Usia Dini. Golden Age: Jurnal Pendidikan Anak Usia Dini, 2(2), 26-34. https://doi.org/10.29313/ga.v2i2.429 $\underline{3}$

Annisa, F. (2019). Penanaman Nilai-Nilai Pendidikan Karakter Disiplin pada Siswa Sekolah Dasar. Jurnal Perspektif Pendidikan dan Keguruan. 10(1), 69-74. https://doi.org/10.25299/perspektif. 2019.vol10(1).3102

Astuti, H. P., \& Wuryandani, W. (2017). Analisis Nilai-nilai Karakter pada Buku Teks Pegangan Guru dan Siswa Kelas VI Sekolah Dasar. Jurnal Pendidikan Karakter, 7(2). https://doi.org/10.21831/jpk.v7i2.17 $\underline{378}$

Dewi, P. P. (2017). Ziarah ke Tanah Makam Jawara. Jakarta: Badan Pengembangan dan Pembinaan Bahasa Kementerian Pendidikan dan Kebudayaan.

Djamari. (2017). Arsitektur Nusantara. Jakarta: Badan Pengembangan dan Pembinaan Bahasa Kementerian Pendidikan dan Kebudayaan.

Efendi, A. (2020). Nilai Karakter dalam Novel Biografi Hatta: Aku Datang karena Sejarah Karya Sergius
Volume 3, Nomor 2, Juli 2021

ISSN 2655-3031 (P), 2655-7851 (O)

DOI: http://dx.doi.org/10.29300/disastra.v3i2.4760

Sutanto. Jurnal Pendidikan Karakter, $\quad 10(1)$. https://doi.org/10.21831/jpk.v10i1.3 $\underline{1269}$

Erminawati, ND. (2018). Jangan Ambil Rumah Kami. Jakarta: Badan Pengembangan dan Pembinaan Bahasa Kementerian Pendidikan dan Kebudayaan.

Fajriniski, Zahar, E., \& Masni, H. (2018). Analisis Pendidikan Karakter Nilai Kasih Sayang pada Novel Padang Bulan Karya Andrea Hirata. Aksara: Jurnal Ilmiah Pendidikan Bahasa Dan Sastra Indonesia, 1(2), 142-150.

http://dx.doi.org/10.33087/aksara.v2 $\underline{\mathrm{i} 1.43}$

Harjani, Mustika D. (2018). Berguru pada Anak Suku Laut Bajo. Jakarta: Badan Pengembangan dan Pembinaan Bahasa Kementerian Pendidikan dan Kebudayaan.

Hartono. (2014). Pendidikan Karakter dalam Kurikulum 2013. Jnana Budaya, 19 (2), 259-268. https://jurnalbpnbbali.kemdikbud.go .id/jurnal/index.php/Jnana/article/vie $\underline{w} / 21$

Hutama, F. S., Anhar, H. A., \& Haidar, D. A. (2019). Muatan Nilai-Nilai Pendidikan Karakter dalam Teks Bacaan pada Buku Siswa Kelas IV Tema Indahnya Kebersamaan. EDUCARE: Journal of Primary Education, $1(1), \quad 85-100$. https://doi.org/10.35719/10.35719

Irma, C. N. (2018). Nilai-nilai Pendidikan Karakter dalam Novel Ibuk Karya Iwan Setyawan. RETORIKA: Jurnal Bahasa, Sastra, dan Pengajarannya, 11(1), 14-22.

Winda Dwi Lestari, Atiqa Sabardila

Menguak Nilai Pendidikan Karakter Buku Bacaan Gerakan Literasi Nasional Kementerian Pendidikan dan Kebudayaan Kelas Rendah Sekolah Dasar 
https://doi.org/10.26858/retorika.v1 $\underline{1 \mathrm{i} 1.4888}$

Jannah, E. M. N., Suwignyo, H., \& Harsiati, T. (2019). Analisis Nilainilai Karakter Hasil Karya Menulis Kreatif Siswa. Jurnal Pendidikan: Teori, Penelitian, dan Pengembangan, 4(2), 149-155. http://dx.doi.org/10.17977/jptpp.v4i $\underline{2.11928}$

Kusumastuti, N., \& Rukiyati, R. (2017). Penanaman Nilai-Nilai Moral Melalui Kegiatan Bercerita pada Anak Usia 5 Tahun. Jurnal Pembangunan Pendidikan: Fondasi dan Aplikasi, 5(2), 162-175 https://doi.org/10.21831/jppfa.v5i2. 14830

Marsudi, S., dkk. (2020). Bimbingan dan Konseling di Sekolah. Surakarta: FKIP UMS.

Mushfi, M., Iq, E., Fadilah, N., \& Jadid, U. N. (2019). Internalisasi Karakter Religius di Sekolah Menengah Pertama Nurul Jadid. Jurnal Mudarrisuna. 9(1), 1-25. http://dx.doi.org/10.22373/jm.v9i1.4 $\underline{125}$

Nurgiyantoro, Burhan. (2010). Teori Pengkajian Fiksi. Yogyakarta: Gadjah Mada University Press.

Purawinangun, I. A. (2020). Menggali Nilai Pendidikan Karakter Berbasis Kearifan Lokal melalui Cerita Rakyat dari Pulau Jawa. Lingua Rima: Jurnal Pendidikan Bahasa Dan Sastra Indonesia, 1, 7-8. http://dx.doi.org/10.31000//grm.v8i $\underline{2.1785}$

Pusat Kurikulum dan Perbukuan, (2011). Panduan Pelaksanaan Pendidikan
Volume 3, Nomor 2, Juli 2021

ISSN 2655-3031 (P), 2655-7851 (O)

DOI: http://dx.doi.org/10.29300/disastra.v3i2.4760

Karakter. Jakarta: Badan Penelitian dan Pengembangan Kemdiknas

Putri, D. P. (2018). Pendidikan Karakter pada Anak Sekolah Dasar di Era Digital. AR-RIAYAH: Jurnal Pendidikan Dasar, 2(1), 37-50. https://doi.org/10.29240/jpd.v2i1.43 $\underline{9}$

Putri, F. P., \& Afnita, A. (2020). Nilai-Nilai Pendidikan Karakter dalam Novel Bumi Karya Tere Liye dan Implikasinya dalam Pembelajaran Bahasa Indonesia. Pendidikan Bahasa Indonesia, 9(2), 9-19. https://doi.org/10.24036/108984$\underline{019883}$

Setyawan, A., Suwandi, S., \& St Y, S. (2017). Muatan Pendidikan Karakter dalam Cerita Rakyat di Pacitan. Jurnal Pendidikan Karakter, $\quad 7(2)$. https://doi.org/10.21831/jpk.v7i2.21 $\underline{778}$

Suyitman. (2017). Minuman Dongeng Nusantara. Jakarta: Badan Pengembangan dan Pembinaan Bahasa Kementerian Pendidikan dan Kebudayaan

Triaristina, A., \& Mukhlis, H. (2019). Implemetasi Pendidikan Karakter melalui Media Dongeng Berbasis Visual pada Anak Usia 4-6 Tahun. Journal of Psychological Perspective, 1(2), 35-40. https://doi.org/10.47679/jopp.11620 $\underline{19}$

Ummi, H. U., \& Mulyaningsih, I. (2017). Nilai Moral dalam Cerita Babad Cirebon: Berdasarkan Penceritaan di Keraton Kanoman. Journal Indonesian Language Education and Literature, 1(2), 207-220. DOI: 24235/ileal.v3i1.1571 
Utomo, E. P. (2018). Internalisasi Nilai Karakter Nasionalis dalam Pembelajaran IPS untuk Membangun Modal Sosial Peserta
Volume 3, Nomor 2, Juli 2021 ISSN 2655-3031 (P), 2655-7851 (O) DOI: http://dx.doi.org/10.29300/disastra.v3i2.4760

Didik. SOCIA: Jurnal Ilmu-Ilmu Sosial, 14(2), 95-102. https://doi.org/10.21831/socia.v14i2 $\underline{.18626}$ 